\title{
Information Content Of Dividend Announcements: An Investigation Of The Indian Stock Market
}

Shania Taneem, Ryerson University, Toronto, Canada

Ayse Yuce Ryerson University, Toronto, Canada

\begin{abstract}
According to the dividend information content hypothesis, dividend changes trigger stock returns because they reflect changes in management's assessment of a firm's future profitability. This hypothesis has motivated a considerable amount of theoretical and empirical research. The general procedure used in prior research begins with classifying the dividend change announcement into either favorable or unfavorable. Dividend policy of companies operating in the emerging markets is very different from the widely accepted dividend policies operating in the developed countries. The purpose of this research is to examine the information content of dividend announcements and price movements in the emerging Indian stock market. The paper investigates the information content and market reaction to dividend announcements using data from the developing Indian market. We focus on the information content of dividend policies through the share price reaction of 82 companies in India that are listed in the Bombay Stock exchange.
\end{abstract}

Keywords: dividend information content; dividend policy

\section{INTRODUCTION}

¿

$\mathrm{n}$ the corporate finance world, companies do not have any obligation to pay dividends. However, we still see a large number of corporations paying out dividends regularly. The crucial question is why do companies pay dividend? Dividend pay-out decision is among the basic policy choices that corporate financial officers make. How much to pay is still an open issue. Dividend policy is considered one of the most crucial issues for management decision because it seems an important way for companies to communicate with market participants. Investors cannot always trust managers to provide unbiased information about their company's prospects, but dividend signals are relatively reliable because they require cash payments and cash cannot be easily manipulated. This is known as the information content of dividends.

A number of researchers have provided insights, theoretical as well as empirical, into the dividend policy puzzle. However, the issue as to why firms pay dividends is yet unresolved. Several rationales for a corporate dividend policy have been proposed in the literature, but there is no unanimity among researchers. The same is with shareholders and investors: some are more interested in dividend and some in capital gain. Every one however, agrees that the issue is important, as dividend announcement is one of the most commonly observed phenomena in the corporations worldwide.

Our understanding of dividend policy depends on the behavior of individual investors, from the early work of Miller and Modigliani (1961) and Gordon (1961) to the more recent behavioral finance theories. Many empirical papers have documented corporate dividend policy and payments, and have related the policies in various ways to the theories based on the behavior of individual investors.

In most other countries, dividends are currently taxed more heavily than capital gains. The difference is material, and thus provides a substantial incentive for investors to prefer to generate income by selling some of their 
shares and to receive no dividends. The finding of Fama and French (2001) shows that the proportion of U.S. firms paying cash dividends has fallen from $66.5 \%$ in 1978 to $20.8 \%$ in 1999 . However, recently dividends have gained renewed attention. The U.S. Congress passed a "tax relief" bill in May 2003 that includes a major change in taxation of investments. Capital gains and dividends are now taxed equally at a top rate of $15 \%$, eliminating the tax penalty on dividends. During the period after the bill was proposed and before it was passed, Microsoft announced that it would start paying dividends for the first time in its 28-year old history. Technology companies such as Cisco and Oracle stated that if dividend taxes were eliminated, they would start paying dividends. This has led to a renewed interest in the question why investors want to receive dividends.

In an emerging country like India, recipients of dividends used to pay income tax. However since June $1^{\text {st }}$, 1997, all domestic companies were liable to pay a dividend distribution tax on the profits distributed as dividends resulting in a smaller net dividend to the recipients. The rate of taxation alternated between $10 \%$ and $20 \%$ until the tax was abolished effectively on March 2002. The dividend distribution tax was also extended to dividends distributed by domestic mutual funds, with the rate alternating between $10 \%$ and $20 \%$ in line with the rate for companies, up to 31 March 2002. Hence the dividends received from domestic companies since June $1^{\text {st }}, 1997$, and domestic mutual funds since 1 June $1^{\text {st }}, 1999$, were made non-taxable for recipients to avoid double-taxation, until 31 March 2002. The budget for the financial year 2002-2003 in India proposed the removal of the dividend distribution tax bringing back the regime of dividends being taxed in the hands of the recipients and the Finance Act 2002 implemented the proposal for dividends distributed since April $1^{\text {st }}, 2002$. This fueled negative sentiments in the Indian share markets causing stock prices to go down. However the next year there were wide expectations for the budget to be friendlier to the markets and eventually the dividend distribution tax was removed. Hence the dividends received from domestic companies and mutual funds since April 1 ${ }^{\text {st }}$, 2003 were again made non-taxable for recipients. As a matter of fact, investors had a lot to cheer from the Budget 2003-04 in India.

This paper explores the market reaction to dividend announcements on stock prices in one emerging market: India. India has been chosen since it is one of top five countries representing the emerging markets. In countries where the stock markets are recently developed, the motivation for managers to use dividends as a signaling mechanism may be stronger in such an environments. A test of the signaling theory in India could shed light on the evidence on the market reaction to dividend changes. The paper investigates the market reaction to dividend announcments in India taking into account 82 companies and assessing whether this can be explained by signaling theory. The study consists of six sections- (II) Stock Markets in India, (III) Previous Studies, (IV) Data and Methodology (V) Empirical Findings and Analysis and (VI) Conclusion.

\section{STOCK MARKETS IN INDIA}

India has 21 recognized stock exchanges but the most active ones are the National Stock Exchange (NSE) and the Bombay Stock Exchange (BSE). The working of stock exchanges in India started in 1875. The history of Indian stock trading starts with 318 people taking membership in the Native Share and Stock Brokers Association, which we now know by the name Bombay Stock Exchange. The Bombay Stock Exchange (BSE) is the oldest stock market in India. In 1965, BSE got permanent recognition from the Government of India. National Stock Exchange (NSE) comes second to Bombay Stock Exchange (BSE) in terms of popularity. BSE and NSE represent themselves as synonyms of Indian stock market. The history of Indian stock market is almost the same as the history of BSE. The 30 stock index or Sensex was first compiled in 1986. In 1990 the BSE crossed the 1000 mark for the first time. It crossed 2000, 3000 and 4000 figures in 1992. There has been a tremendous growth in market turnover and market capitalization of listed companies during the post-liberalization period. The overall growth, however, has been accompanied by heavy concentration in a few companies and sectors. While 5,782 companies were listed at BSE at the end of March 2007, only 3,223 were traded any time during 2006-07 i.e., 2,559 companies were not traded at all during the year.

The initial euphoria created by liberalization helped mobilize a large amount of resources from the market. Far from raising resources directly from the investors, companies, for the past few years have been, however, resorting to private placements and borrowings (Table-I). 
Table I: Mobilization Of Resources: Increasing Share Of Private Placements

\begin{tabular}{|c|c|c|c|}
\hline Year & $\begin{array}{c}\text { Total Domestic } \\
\text { Issues (Rs. Crores) }\end{array}$ & $\begin{array}{c}\text { Of which, Private } \\
\text { Placement (Rs. Crores) }\end{array}$ & $\begin{array}{c}\text { Share of Private } \\
\text { Placements in Total (\%) }\end{array}$ \\
\hline $1996-97$ & 14,219 & 4,244 & 29.85 \\
\hline $1997-98$ & 16,366 & 4,463 & 27.27 \\
\hline $1999-00$ & 23,286 & 1,635 & 7.02 \\
\hline $2000-01$ & 37,044 & 7,466 & 20.15 \\
\hline $2001-02$ & 41,974 & 11,174 & 26.62 \\
\hline $2002-03$ & 36,193 & 13,361 & 36.92 \\
\hline $2003-04$ & 37,738 & 30,099 & 79.76 \\
\hline $2004-05$ & 59,044 & 49679 & 84.14 \\
\hline $2005-06$ & 68,963 & 61,259 & 88.83 \\
\hline $2006-07$ & 73,922 & 67,500 & 91.31 \\
\hline
\end{tabular}

Source: National Stock Exchange, Indian Securities Market: A Review, Vol. IV, 2001

\section{PREVIOUS STUDIES}

There is an extensive "event study" literature that investigates the informational content of market announcements such as firms dividend levels. The influential papers by Ball and Brown (1968) and Beaver (1968) were followed by many others in this field, such as those by Aharony and Swary (1980), Kalay and Loewenstein (1985), Marsh (1992), and Sant and Cowan (1994). The present study is carried out within the framework of this literature, analyzing differences in information conveyed by dividend announcements.

Two of the early extensive empirical studies measuring the impact of dividend on stock prices were Pettit (1972) and Watts (1973). Pettit (1972) studied a sample of 67 firms in US that were paying out regular dividends for the period of 1968-1970 to find that market participants make considerable use of information implicit in announcements of changes in dividend payments. However, Watts (1973) took into account 104 dividend paying firms in US as well for the period of five years (i.e. from 1965-1970) and concluded that examining the relationship between unexpected dividend changes and stock prices indicates that these changes communicate no information beyond that reflected in other contemporaneous variables (e.g. earnings).

The theoretical literature on dividend effects has been well-developed. Researchers largely accepted that dividend per-se has no impact on the shareholder's value in an ideal economy. However, in a real world, the dividend announcement is important to the shareholders because of its tax effect and information content. The Signaling Theory suggests that when a company announces an increase in dividend payouts then this acts as an indicator of the firm possessing strong future prospects. The information content hypothesis states that dividend announcements are used by managers as a way to signal shareholders in respect of future prospects of the firm. In fact, a fundamental question in corporate finance has been whether changes in dividend policy convey information about the firm's performance in capital markets. Tests of significance of dividend changes showed that capital markets react favorably to "good news" announcements (dividend increases) and adversely to "bad news" announcements (dividend cuts), supporting the view that dividend changes have an information content (Michaely, Thaler and Woack, 1995). It should be noted that the market reaction to dividend cut is far greater than the market reaction to a dividend increase (Benesh, Keown and Pinkerton, 1984; Eades, Hess and Kim, 1985), Ang (1987), Allen and Michaley (1997), Lease John, Kalay, Lowenstein and Sarig (2000))

Whether or not dividend announcements have any information content is a question that has evolved through multiple stages. In the early stage of the related literature, it was simply of interest to test whether or not the market reacts to these announcements. The research conducted during this stage examined either dividend initiations or omissions (e.g. Asquith and Mullins 1983, Ghosh and Woolridge 1988), or dividend changes in general (e.g. Aharony and Swary 1980, Woolridge 1982, and Eades, Hess and Kim 1985). Some evidence was documented by Benesh, Keown, and Pinkerton (1984), when they examined the market reaction to substantial shifts in dividend policy.Their results suggest that announcements of dividend omission and large decreases have, on average a pronounced negative impact on stock prices, while the market's reaction to dividend initiations and large increases is positive. Their findings support the informational content of dividend hypothesis and that the market's reaction to 
unfavorable dividend announcements is much greater than for favorable announcements. Born, Moser, and Officer (1987) provide evidence that dividend policy change announcements are associated with abnormal returns and conclude that the market does respond to unexpected changes in dividend policy, which indicates that dividend policy is relevant; what remains is to understand which aspects of the information are relevant.

Healy and Palepu (1988) focus on dividend initiations and omissions, the two dividend policy changes that have been documented in the literarature as having the largest average announcement returns. Consistent with the dividend information hypothesis, their findings indicate that the information conveyed by dividend initiations and omissions are related to earnings changes following the announcement of these dividend policy changes. Investors therefore, interpret dividend initiations and omissions as changes in the management's earnings forecast. Ghosh and Woolridge (1991) and Sant and Cowan (1994) report significant negative reactions to dividend omission announcements.

Easterbrook (1984) suggets that dividends reduce the agency costs associated with the separation of ownership and control. He argues that increases in dividend payments increase the frequency with which managers must raise funds in external capital markets. This activity reduces agency costs by subjecting managers to the professional monitoring of outsiders such as investment bankers,lawyers, and accountants. Easterbrook's analysis predicts that the market responds positively to dividend increase announcements because it incorporates the value of additional monitoring into stock price.

Based on their of 647 earnings and dividend announcements made by Australian Companies over the period 1963 to 1969, Brown, Finn and Hancock (1977, hereafter BFH) found that these announcements have an interactive informational effect on share prices - the size of abnormal stock returns appeared to depend on both the magnitude and the direction of earnings and dividend changes. However, emerging markets add more pieces to the "dividend puzzle" and have recently attracted researchers trying to explain the dividend policy behavior of corporations operating in these markets (Glen Karmokolias, Miller, and Shah, 1995). However, it is still not satisfactorily explained why corporations distribute a portion of their earning as dividend or why investors pay attention to dividends.

Therefore, the present study will look into the dividend payment approach of different Indian companies and would try to determine the implications of varying policies. The study will also try to find out the reasons as to whether investors pay attention to dividends or not when making investment decisions.

\section{DATA AND METHODOLOGY}

This research is concerned with the information content of dividend announcement and stock market behavior. The aim of the study is to analyze whether different types of dividend announcements, dividend cuts and dividend rises, convey information with differing degrees of precision. We will test the following hypotheses:

\section{Hypothesis 1:}

Ho: There will be a positive significant return in stocks when there is an announcement about a dividend increase.

\section{Hypothesis 2:}

Ho: There will be a negative significant return in stocks when there is an announcement about a dividend decrease.

In total 1,985 Indian companies were found to be listed by Datastream. These 1,985 companies were chosen as the initial sample listed under the Bombay Stock Exchange. Of these, 906 companies did not have the adjusted prices and therefore no information was available for them. This reduced the number of companies to 1079. The following companies were excluded from the sample: companies not paying dividends, companies that had no change in dividends, companies that did not pay regular dividends during the period chosen, companies that were not traded regularly and companies that were delisted. These criteria reduced the sample size to 82 companies. 
The data included the stock prices of 82 companies in India from 21 different industries. The data for the daily stock prices and the dividend amounts were drawn from Datastream. The financial statements of the relative companies were also used to get more insight information. The requirement for data on share price and dividend announcements provided a final sample of 82 firms over the period of 2004-2007. Table II lists the industrial composition of these companies. The final sample was found to be a good proxy for the overall Indian Stock exchange market.

Table II: Sample Descriptive Characteristics

\begin{tabular}{|l|c|c|}
\hline \multicolumn{1}{|c|}{ Industry Classification } & Number of Firms & \% of Firms \\
\hline Automobile and Parts & 7 & 10.00 \\
\hline Banks & 10 & 7.7 \\
\hline Chemical & 6 & 14.7 \\
\hline Construction Materials & 12 & 4.3 \\
\hline Electricity & 1 & 2.5 \\
\hline Electronic and Electrical Equipment & 4 & 4.9 \\
\hline Forestry And Paper & 2 & 1.3 \\
\hline General Industrials & 4 & 6.5 \\
\hline Health care and Hospitals & 1 & 2.5 \\
\hline Industrial Engineering & 5 & 1.3 \\
\hline Industrial Metal \& Mining & 2 & 2.5 \\
\hline Mining & 1 & 6.5 \\
\hline Oil and Gas & 2 & 3.7 \\
\hline Pharmaceuticals \& Biotechnology & 5 & 1.3 \\
\hline Personal Goods & 3 & 9.8 \\
\hline Real Estate & 1 & 3.7 \\
\hline Software & 8 & 2.5 \\
\hline Technology Hardware \& Equipment & 3 & \\
\hline Textile & 2 & \\
\hline Travel \& Leisure & 1 & \\
\hline Tobacco & 2 & \\
\hline Total & 82 & \\
\hline
\end{tabular}

Dividend announcement dates were obtained from Moneycontrol.com which sourced all its data from Asian CERC. The dividend amounts were double checked with DataStream and Moneycontrol.com to avoid any mistake. We will call 37 companies that reduced their dividends as the Bad News Sample. Similarly we will classify 45 companies that raised their dividends as the Good News Sample.

The Market Model will be used for the analysis of the data. It is often employed to measure residual terms as risk adjusted abnormal performance. The market model is used to measure the abnormal returns:

$\mathrm{AR}_{\mathrm{it}}=\mathrm{R}_{\mathrm{it}}-\alpha_{\mathrm{i}}-\beta_{\mathrm{i}} \mathrm{R}_{\mathrm{mt}}$

$\mathrm{R}_{\mathrm{it}}$ is the time $t$ returns on security $\mathrm{i}$, calculated as $\left(\mathrm{P}_{\mathrm{it}}-\mathrm{P}_{\mathrm{it}-1}\right) / \mathrm{P}_{\mathrm{it}-1}$. Where, $\mathrm{P}_{\mathrm{it}}$ is the market closing price of stock $i$ on day $t . \mathrm{P}_{\mathrm{it}-1}$ is the market closing price of stock $i$ on day $t-1$.

$R_{m t}$ is the time $t$ return on the BSE-500 price index calculated as $\left(\mathrm{I}_{\mathrm{it}}-\mathrm{I}_{\mathrm{t}-1}\right) / \mathrm{I}_{\mathrm{t}-1}$. Where, $\mathrm{I}_{\mathrm{it}}$ is the market index on day $t$. $\mathrm{I}_{\mathrm{t}-}$ ${ }_{1}$ is the market index on day $\mathrm{t}-1$.

$\mathrm{AR}_{\mathrm{it}}$ is the abnormal (residual) return for firm $i$ on day $\mathrm{t}$.

We used a maximum event window of $[-20,+20]$ for daily event-study analysis to capture the announcement effect. The day of announcement is defined as day 0 . Therefore the market model will be used to measure abnormal returns. The estimation window is 250 trading days from -280 to day -31 . The cumulative abnormal returns (CAR) were calculated as follows: 
$\operatorname{CAR}\left(\tau_{1}, \tau_{2}\right)=\sum_{\tau=\tau 2}^{\tau 2} \operatorname{AR}_{\mathrm{it}}$

The following event windows are used to calculate the cumulative abnormal return:

CAR $(-1,+1)$ as CAR3, CAR $(-2,+2)$ as CAR5, CAR $(-5,+5)$ as CAR11, CAR $(-7,+7)$ as CAR15.

\section{EMPIRICAL FINDINGS AND ANALYSIS}

Table III describes the daily returns from day -20 to day +20 . We can see that the average mean daily returns are positive on almost all days for both the samples, while on the event day the returns for the Bad News Sample (i.e. for companies that declare a decrease in dividend) is negative and the returns for the Good News sample (i.e. companies that declare an increase in dividend) is positive. This indicates an average price decrease on the event day for the Bad News Sample. From this result, we can say that investors have the perception, that if companies increase their dividend payment amount this means that the company is in a better position and that the earnings of the company have increased which is why they have decided to increase the dividend amount and vice versa for companies that declared a decrease in the dividend amount.

Table III: Daily Returns Around Dividend Announcements For The Good News Sample (GN) And The Bad News Sample (BN)

\begin{tabular}{|c|c|c|c|c|c|}
\hline Day & GN Sample & BN Sample & Day & GN Sample & BN Sample \\
\hline-20 & 0.0024 & 0.0029 & 0 & 0.0070 & -0.0218 \\
\hline-19 & 0.0060 & 0.0044 & +1 & 0.0045 & -0.0030 \\
\hline-18 & 0.0043 & 0.0052 & +2 & 0.0050 & 0.0039 \\
\hline-17 & 0.0055 & 0.0077 & +3 & 0.0058 & 0.0047 \\
\hline-16 & 0.0017 & 0.0064 & +4 & 0.0014 & -0.0046 \\
\hline-15 & 0.0038 & 0.0039 & +5 & 0.0048 & 0.0022 \\
\hline-14 & 0.0056 & 0.0055 & +6 & 0.0054 & 0.0104 \\
\hline-13 & 0.0030 & 0.0028 & +7 & 0.0028 & 0.0027 \\
\hline-12 & 0.0031 & 0.0052 & +8 & 0.0045 & 0.0041 \\
\hline-11 & 0.0020 & 0.0076 & +9 & 0.0037 & 0.0022 \\
\hline-10 & 0.0037 & 0.0057 & +10 & 0.0032 & -0.0037 \\
\hline-9 & 0.0007 & 0.0055 & +11 & 0.0025 & 0.0034 \\
\hline-8 & 0.0045 & 0.0014 & +12 & 0.0047 & 0.0089 \\
\hline-7 & 0.0029 & 0.0071 & +13 & 0.0043 & 0.0044 \\
\hline-6 & 0.0053 & 0.0070 & +14 & 0.0051 & -0.0136 \\
\hline-5 & 0.0059 & 0.0073 & +15 & 0.0045 & 0.0026 \\
\hline-4 & 0.0032 & 0.0105 & +16 & 0.0064 & -0.0065 \\
\hline-3 & -0.00007 & 0.0064 & +17 & 0.0012 & 0.0050 \\
\hline-2 & 0.0046 & -0.0015 & +18 & 0.0046 & 0.0017 \\
\hline-1 & 0.0058 & 0.0060 & +19 & 0.0054 & 0.0033 \\
\hline- & - & - & +20 & 0.0097 & 0.0074 \\
\hline
\end{tabular}

The findings in Table III are generally supportive of the view taken in earlier studies that announcement of dividends by firms generate positive abnormal returns to their shareholders especially in the case of increasing dividends. The findings support strongly that favorable announcements possess positive information, while unfavorable announcements possess negative information and the market reacts accordingly. Therefore, it can be said that the market reacted negatively to the dividend decrease. Accordingly, we infer from this reaction that the market expects future earnings also to decrease, thus suggesting a positive relation between the market's expectations for future earnings and dividend decreases.

Table IV, Panel A shows the abnormal returns for the Good News Sample, and for the Bad News Sample. We can see that for the Good News Sample the AR's are positive for most of the days, while for the Bad News Sample more than half of them are negative. On day 0, The AR is positively significant for the Good News Sample $(\mathrm{AR}=0.43 \%)$, while negatively significant for the Bad News Sample ( $\mathrm{AR}=-2.23 \%)$. As can be seen from the above 
results, on Day 0, for the Good News Sample the AR is positive and ( $\mathrm{t}$-value $\left.=2.45^{*}\right)$. This market reaction implies increases in dividends release positive information about the firm. The results for the Bad News Sample shows that the AR is negative and ( $\mathrm{t}$-value $=-8.52^{*}$ ). This indicates that dividend decreases release negative information to the market. Overall the results indicate significant market reactions on the announcement date to positive and negative dividend changes. And the results are consistent with signaling theory.

Table IV: Abnormal Returns And t-value For Good News Sample, Bad News Sample

\begin{tabular}{|c|c|c|c|c|}
\hline \multirow[b]{2}{*}{ Day } & \multicolumn{2}{|c|}{ Good News Sample } & \multicolumn{2}{|c|}{ Bad News Sample } \\
\hline & $\mathbf{A R}$ & t-Value & $\mathbf{A R}$ & t-Value \\
\hline-20 & 0.0013 & 1.45 & 0.0006 & 0.52 \\
\hline-19 & 0.0014 & 1.47 & -0.00003 & -0.02 \\
\hline-18 & 0.0022 & $2.08 * *$ & 0.0005 & 0.41 \\
\hline-17 & 0.0021 & $1.95 * *$ & -0.0009 & -0.65 \\
\hline-16 & -0.0001 & -0.10 & 0.0010 & 0.72 \\
\hline-15 & 0.0012 & 1.10 & 0.0002 & 0.14 \\
\hline-14 & 0.0026 & $2.30 * *$ & 0.0016 & 1.21 \\
\hline-13 & 0.0017 & 1.46 & -0.0008 & -0.61 \\
\hline-12 & 0.0016 & 1.45 & -0.0002 & -0.11 \\
\hline-11 & 0.0005 & 0.44 & 0.0015 & 0.98 \\
\hline-10 & 0.0031 & $2.56^{*}$ & 0.0007 & 0.54 \\
\hline-9 & -0.0006 & -0.50 & 0.0036 & $2.77 *$ \\
\hline-8 & 0.0028 & $2.44^{*}$ & -0.0034 & $-2.72 *$ \\
\hline-7 & 0.0004 & 0.37 & 0.0012 & 0.80 \\
\hline-6 & 0.0028 & $2.37 * *$ & 0.0010 & 0.65 \\
\hline-5 & 0.0027 & $2.43 *$ & -0.0009 & -0.63 \\
\hline-4 & 0.0006 & 0.50 & -0.0033 & $-2.26 * *$ \\
\hline-3 & -0.0006 & -0.53 & -0.0057 & $-3.56^{*}$ \\
\hline-2 & 0.0010 & 0.74 & -0.0159 & $-7.89 *$ \\
\hline-1 & 0.0033 & $2.21 * *$ & -0.0057 & $-2.42 *$ \\
\hline 0 & 0.0043 & $2.45 *$ & -0.0223 & $8.52 *$ \\
\hline+1 & 0.0019 & 1.07 & -0.0071 & $-3.32 *$ \\
\hline+2 & 0.0020 & 1.36 & -0.0035 & $-2.17 * *$ \\
\hline+3 & 0.0007 & 0.57 & -0.0063 & $-3.70^{*}$ \\
\hline+4 & -0.0002 & -0.21 & -0.0002 & -0.12 \\
\hline+5 & 0.0016 & 1.31 & 0.0019 & 1.25 \\
\hline+6 & 0.0013 & 1.10 & 0.0077 & $4.58 *$ \\
\hline+7 & 0.0002 & 0.18 & 0.0020 & 1.14 \\
\hline+8 & 0.0030 & $2.60 *$ & 0.0035 & 1.98 \\
\hline+9 & 0.0017 & 1.50 & 0.0028 & 1.83 \\
\hline+10 & 0.0021 & $1.69 * *$ & -0.0037 & -2.00 \\
\hline+11 & -0.0004 & -0.33 & -0.0031 & -1.66 \\
\hline+12 & 0.0019 & 1.63 & -0.0020 & -1.06 \\
\hline+13 & 0.0013 & 0.87 & 0.0033 & $1.68 * *$ \\
\hline+14 & 0.0011 & 0.85 & 0.0007 & 0.30 \\
\hline+15 & 0.0019 & 1.46 & 0.0002 & 0.10 \\
\hline+16 & 0.0042 & $2.52 *$ & -0.0026 & -1.14 \\
\hline+17 & 0.0009 & 0.64 & 0.0010 & 0.44 \\
\hline+18 & 0.0025 & $1.90 * *$ & 0.0040 & $1.80 * *$ \\
\hline+19 & 0.0025 & 1.11 & 0.0054 & $3.02 *$ \\
\hline+20 & 0.0028 & $2.92 *$ & 0.0026 & 1.32 \\
\hline
\end{tabular}

*significant at 0.01 level, **significant at 0.05 level

Table V shows the CAR values for Good News Sample and Bad News Sample and their corresponding Zvalues. For the pre-event window of $[-20,-3]$, the CAR is $2.57 \%$ (positively significant at the 0.01 level) for the Good News Sample and $-0.32 \%$ for the Bad News Sample (not significant), indicating again that the market anticipates increase in dividend before announcements, and there does exist information leakage. 
Table V: CAR For Good News Sample And Bad News Sample And Their Corresponding Z-Values

\begin{tabular}{|c|c|c|c|c|}
\hline & \multicolumn{2}{|c|}{ Good News Sample } & \multicolumn{2}{c|}{ Bad News Sample } \\
\hline Interval & CAR & Z-Value & CAR & Z-Value \\
\hline$[-20,2]$ & 0.0382 & $6.45^{*}$ & -0.0578 & $-5.45^{*}$ \\
\hline$[-20,-3]$ & 0.0257 & $5.47^{*}$ & -0.0032 & -0.43 \\
\hline$[-5,5]$ & 0.0173 & $3.54^{*}$ & -0.0690 & $-10.05^{*}$ \\
\hline$[-2,2]$ & 0.125 & $3.44^{*}$ & -0.0545 & $-10.87^{*}$ \\
\hline$[-1,1]$ & 0.0095 & $3.22^{*}$ & -0.0351 & $-8.23^{*}$ \\
\hline
\end{tabular}

*significant at 0.01 level

As for the shorter intervals around announcements, CAR's are significantly positive at the 0.01 level for the good news sample for all the intervals; between $0.95 \%$ for $[-1,1]$ and 1.73 for $[-5,5]$. On the other hand, CAR's are significantly negative at the 0.01 level for the Bad News Sample for all the shorter intervals; between $-6.90 \%$ for $[-5$, 5] and $-3.51 \%$ for $[-1,1]$. These results suggest that announcements affect stock prices. There is a positive relationship between abnormal returns and dividend announcements, and reactions to bad news are more intensive.

We can see that the CARs for the Good News Sample for the different intervals are all positive and the CARs for the Bad News Sample are all negative. This means that the stocks of companies that declared a decrease in dividends could not earn a positive cumulative abnormal return and vice versa. And the corresponding $Z$-values for the Good News Sample are positive and negative for the Bad News Sample. The results indicate that the Bad News Stocks lies on the left of the curve and the Good News Stocks lie on the right half of the curve. Thus we accept Hypothesis 1 and Hypothesis 2, since we can see that Good News Sample has a positive return and the Bad news Sample has a negative return and the $t$-values are significant at the 0.01 level of significance. The result is consistent with the fact that dividend announcements have information content and can by themselves, induce share price adjustments. "Good News"-that is the current dividend exceeds last year's level-is followed by positive price reactions and vice versa. Therefore, it can be said that there is a positive relation between the announcement of increased dividend and stock price. An increased dividend announcement leads to an increase of the corresponding company's stock price and investors react positively to the announcement.

Table VI shows that the Bad News Sample has a greater mean absolute value of Cumulative Abnormal Return (ICARI) than the Good News Sample. The mean ICARIs for the Bad News Sample are significantly higher than those of the Good News Sample across all four intervals. Hence we can say from these results that the unconditional stock price response to bad news disclosures is larger than that for the good news disclosure. Therefore, from Table VI, we can see that the results strongly support our Hypothesis 2.

Table VI: Two- Sample Comparison For Absolute Value Cumulative Abnormal Returns Between Good News Sample And Bad News Sample

\begin{tabular}{|l|c|c|c|c|}
\hline & CAR3 & CAR5 & CAR11 & CAR15 \\
\hline Good News Sample & 0.0457 & 0.0561 & 0.0773 & 0.0865 \\
\hline Bad News Sample & 0.0606 & 0.0802 & 0.1023 & 0.0993 \\
\hline Difference in Mean CAR & -0.0149 & -0.0241 & -0.025 & -0.0128 \\
\hline
\end{tabular}

CAR3 is the current year's cumulative abnormal return for 3-day interval (-1 to +1). CAR5 is the current years abnormal return for 5-day interval ( -2 to +2$)$. CAR11 is the current year's abnormal return for 11 -day interval $(-5$ to +5$)$. CAR15 is the current year's abnormal return for the 15 day interval $(-7$ to +7$)$.

\section{CONCLUSION}

A dividend payment provides cash flow to the shareholders, but it reduces firm's resource for future investments. Hence, firms should not pay dividends if they have any positive net present value project in the offing. However, Walter (1956) and Gordon (1959 and 1962) showed that the valuation of stock depends on the expected future dividends. If a company pays out all the earnings to shareholders, funding for future investment will decrease and dividend may not increase in the future. Moreover, cash dividend is not desirable if investors need to pay taxes on their dividend income. Given the valid reasons for not paying dividends, an announcement of dividend payments may carry some information for the market and stock prices may be adjusted accordingly. 
Based on the results above for the 82 BSE enlisted companies, which announced dividends during the financial years 2004-2007, we can see that investors have a favorable reaction towards companies that increased their dividends and the vice versa for companies that declared a decrease in dividend. From the results we can conclude that dividend announcements have information content and can, by themselves, induce share price adjustments.

The results of the study also showed that companies that increased their dividend amounts had a higher abnormal return and higher cumulative abnormal return showing once again that the market has a favorable impression towards companies paying out higher dividends.

In general, the event study findings strongly support the dividend signaling hypothesis in explaining the positive price reactions to an increase in the dividend payment. The results indicate that firms operating in the Bombay Stock Exchange are not an exception: the stock price will move in the direction of the dividend change.

\section{BIBLIOGRAPHY}

1. Aharony, J. and Swary, I. “Quarterly Dividend and Earnings Announcement and Stockholders' Returns: An empirical Analysis". Journal of Finance, Vol. 35, pp.1-12 (1980)

2. Arriff, M. and Finn, F. J. "Announcement Effects and Market Efficiency in a Thin Market: An Empirical Application to the Singapore Equity Market”. Asia Pacific Journal of Management, Vol.6, pp.243-267 (1986)

3. Atiase, R. K. "Pre-disclosure Information, Firm Capitalization, and Security Price Behavior around Earnings Announcements". Journal of Accounting Research, Vol.23, pp.21-36 (1985)

4. Ball, R. and Brown, P. "An Empirical Evaluation of Accounting Income Number”. Journal of Accounting Research, Vol. 6, pp.159-178 (1968)

5. Ball, R. and Kothari, S.P. "Security Returns around Dividend Announcements". The Accounting Review, Vol.66, pp.718-738 (1991)

6. Beaver, W., Clarke, R. and Wright, W. "The Association between Unsystematic Security Returns and the Magnitude of Dividend Forecast Errors". Journal of Accounting Research, Vol.17, pp.316-340 (1979)

7. Begley, J. and Fischer, P. E. "Is There Information in an Dividend Announcement Delay?". Review of Accounting Studies, Vol.3, pp.347-363 (1998)

8. Bhattacharya, S. "Imperfect Information, Dividend Policy, and 'the bird in the hand' Fallacy". The Accounting Review, Vol.10, pp.259-270 (1979)

9. Black, F. and Scholes, M. "The Effect of Dividend Yield and Dividend Policy on Common Stock Prices and Returns". Journal of Accounting Research, Vol.1, pp.1-22 (1974)

10. Brealy and Myers "Principles of Corporate Finance", $7^{\text {th }}$ Edition, McGraw-Hill Inc.

11. Chambers, A. E. and Penman, S. H. "Timeliness of Reporting and the Stock Price Reaction to Dividend Announcement". Journal of Accounting Research, Vol.22, pp21-47 (1984)

12. Chang, S. J. and Chen, S. N. "Information Effects of Earnings and Dividend Announcements on Common Stock Returns: Are they Interactive?". Journal of Economics and Finance, Vol.43, pp.179-192 (1991)

13. Hamiduddin, M. "Effect of Dividend Announcement on Shareholders' Value: Evidence from Dhaka Stock Exchange". The International Review of Finance, In press (2003)

14. Jensen, M. and Meckling, W. "Theory of Firm; Managerial Behavior, Agency Cost and Ownership Structure". Journal of Finance, Vol.3, pp. 306-360 (1976)

15. Kato, K. and Loewenstein, U. "The Ex-dividend Day Behavior of Stock Prices: The Case of Japan". The Review of Financial Studies, Vol.8, pp.816-847 (1995)

16. Litzenberger, R. H. and Ramaswamy, K. "The Effects of Personal Taxes and Dividends on Capital Assets Prices". Journal of Financial Economics, Vol.7, pp.163-195 (1979)

17. Miller, M. H. and Modigliani, F. "Dividend Policy, Growth and the Valuation of Shares". The Journal of Business, Vol.34, pp.411-433 (1961)

18. Porterfield, J. T. S. "Dividend, Dilution and Delusion". Harvard Business Review, Vol.37, pp.56-61 (1959)

19. Stevens, J. L. and Jose, M. L. "The Effect of Dividend Payout, Stability, and Smoothing of Firms Value". Journal of Accounting and Finance, Vol. 7, pp.195-216 (1992)

20. Walter, J. E. "Dividend Policies and Common Stock Prices". Journal of Finance, Vol.16, pp.29-41 (1956) 


\section{NOTES}

